\title{
Anal Canal Squamous Cell Papilloma
}

National Cancer Institute

\section{Source}

National Cancer Institute. Anal Canal Squamous Cell Papilloma. NCI Thesaurus. Code C96554.

A benign epithelial neoplasm that arises from the anal canal. It is characterized by a papillary growth pattern and a proliferation of neoplastic squamous cells without morphologic evidence of malignancy. 